\title{
Article \\ Hematological Status in Neonatal Jaundice Patients and Its Relationship with G6PD Deficiency
}

\author{
Nilufa Akhter ${ }^{1}$, Noorzahan Begum ${ }^{2}$, Sultana Ferdousi ${ }^{3}$
}

\begin{abstract}
Background: The role of hemolysis in the pathophysiology of neonatal jaundice in patient with G6PD deficiency. Objectives: To observe the hematological status of hyperbilirubinemic neonates and its corelation with G6PD deficient neonates. Methods: The study was conducted on 90 male, term neonates with jaundice, age ranged from 3 to 12 days (Group B) in the Department of Physiology, Bangabandhu Sheikh Mujib Medical University (BSMMU) between $1^{\text {st }}$ July 2007 to $30^{\text {th }}$ June 2008. On the basis of total serum bilirubin (TSB) level, study group was further divided into $\mathrm{B}_{1}$-TSB $<15 \mathrm{mg} /$ $\mathrm{dl}, \mathrm{B}_{2}$-TSB 15 to $20 \mathrm{mg} / \mathrm{dl}$ and $\mathrm{B}_{3}-\mathrm{TSB}>20 \mathrm{mg} / \mathrm{dl}$. For comparison age and sex matched 30 apparently healthy neonates (Group A) were also included in the study. Erythrocyte G6PD level was measured by Spectrophotometric method by using kit of Randox. Hematological parameters like hemoglobin concentration, hematocrit, total count of RBC, reticulocyte count were measured by standard laboratory technique. For statistical analysis anova, independent sample t test and Pearson's correlation coefficient test were performed as applicable by using SPSS for windows version-12. Results: In this study, hemoglobin concentration, hematocrit value and RBC count were significantly lower in both moderate $(\mathrm{p}<0.05)$ and severe $(\mathrm{p}<0.01)$ groups in comparison to those of control and also in mild group. However, these values were statistically not significant between study groups. Similarly, all these values were lower in G6PD deficient neonates than that of non deficient neonates but it was statistically non significant. Again, reticulocyte count was significantly $(\mathrm{p}<0.001)$ higher in severe hyperbilirubinemic than those of control, mild and moderate group. Hemoglobin concentration, hematocrit, total count of red blood cell and reticulocyte count showed non significant positive correlations $(r=+.745, r=+.205$, $\mathrm{r}=+.329, \mathrm{r}=+.104$ ) with erythrocyte G6PD level in deficient neonates. Conclusion: Hemolysis is one of the risk factor to develope hyperbilirubinemia in G6PD deficient neonates and degree of hemolysis depends on state of deficiency.
\end{abstract}

J Bangladesh Soc Physiol. 2011 June; 6(1): 16-21 For author affiliations, see end of text.

http://www.banglajol.info/index.php/JBSP

\section{Introduction}

$\mathbf{G}$ lucose-6-phosphate dehydrogenase (G6PD) is an enzyme that catalyses the first step of hexose monophosphate shunt. This enzyme provides pentoses for nucleic acid synthesis and generates NADPH. In erythrocyte, NADPH is used to form reduced glutathione in a reaction catalyzed by glutathione reductase. G6PD helps to protect RBC from oxidative stress ${ }^{1}$. Though most of the G6PD deficient subjects show no symptoms but they are vulnerable to develop hemolysis \& neonatal jaundice following intake of certain food or drugs $^{2}$. Glucose-6-phosphate dehydrogenase deficiency is a genetically determined $\mathrm{X}$-linked disorder, primarily affects male ${ }^{3}$. The prevalence

J Bangladesh Soc Physiol. 2011 June; 6(1): 16-21 
of G6PD enzyme deficiency is high in Africa, the South East Asia, the Mediterranean the Middle East and also in population of the Indian subcontinent ${ }^{4}$. In the last two decades, numerous studies have demonstrated that G6PD deficiency is a potential cause of neonatal jaundice. They also reported that significantly higher serum bilirubin level is a usual finding in neonates with G6PD deficiency ${ }^{5,6}$. Incidence of neonatal jaundice is significantly higher in G6PD deficiency in comparison to that of non deficient neonates ${ }^{7}$. Numerous studies have been demonstrated that in this enzyme deficient case hyperbilirubinemia results from excessive destruction of red blood cells ${ }^{8}$. Lower level of hemoglobin concentration, hematocrit value and total count of red blood cells, in G6PD deficient neonates with hyperbilirubinemia were observed by some investigators from different countries 9,10,11. It has been shown that reticulocytes count was found higher in G6PD deficient neonates with hyperbilirubinemia ${ }^{10,12}$. However, no significant change in this parameter was reported by other investigators in G6PD deficient neonates with hyperbilirubinemia ${ }^{13}$.

Though, a few study was done to observe G6PD status in adult ${ }^{14}$ no study has yet been explored the hematological parameters of these G6PD deficient neonates in our country. In addition, there is lack of adequate information regarding G6PD deficiency in hyperbilirubinemic neonates and also their hematological parameter. Therefore, the present study was undertaken to observe hematological changes in this group of neonates and their relationship with G6PD level.

\section{Methods}

The present cross sectional study was carried out in the Department of Physiology, BSMMU, Dhaka between July 2007 to June 2008 and the protocol was approved by the Ethical Committee of BICH \& Department of Physiology BSMMU, Dhaka. A total number of 120 male, term, neonates, within age range 3-12 days with and without jaundice were included in this study. Thirty apparently healthy neonates without jaundice was considered as control (group-A) and 90 neonates with jaundice were considered as study group (group-B). On the basis of TSB the study group was divided into three subgroups, group $\mathrm{B}_{1}$ having TSB $<15 \mathrm{mg} / \mathrm{dl}$, group $\mathrm{B}_{2}$ i,e TSB from 15 to $20 \mathrm{mg} / \mathrm{dl} \&$ group $B_{3}$ i,e TSB $>20 \mathrm{mg} / \mathrm{dl}$. Neonates having Rh incompatibility, sepsis and cephalohematoma were excluded from the study. Control group was selected from Out Patient Department and study groups were selected from In Patient Department of Dhaka Shishu Hospital, Dhaka. After selection of the subjects, aims, objectives and detail procedure of the study and the benefit of the child from the study were explained to the parents and they were encouraged for voluntary participation and written informed consents were also taken from them. The cases of jaundice was diagnosed by clinical examination and higher total serum bilirubin level, corresponding to gestational age \& body weight. Parents were interviewed for detail history and thorough physical examinations of all the neonates were done on the $1^{\text {st }}$ day of their visit/admission into the hospital. All informations were recorded in a prefixed questionnaire. Then $2.5 \mathrm{ml}$ of venous blood was collected for estimation of erythrocyte G6PD level, serum bilirubin, hemoglobin concentration, hematocrit value, TC of RBC, reticulocyte count in order to evaluate their hemolytic status. Erythrocyte G6PD level was estimated by using kit of Randox ${ }^{15}$. Serum bilirubin level was measured by Modified Jendrassik/Grof method ${ }^{16}$. Hemoglobin was estimated by cyanmethemoglobin method. Total count of RBC was done by hemocytometry ${ }^{17}$, hematocrit by Macrohematocrit ${ }^{17}$ and reticulocyte count by Brilliant cresyl blue method ${ }^{17}$. Data were expressed by mean \pm SD. Data analysis was done by using SPSS windows version-12.For statistical significance, anova, Independent sample t test, Chi-Square test and Pearson's correlation coefficient test were performed as applicable.

\section{Results}

The mean $( \pm \mathrm{SD})$ age and weight of all subjects were almost similar and they were matched for age and sex. 


\section{Article Hematological Status in Neonatal Jaundice Patients and Its Relationship with G6PD Deficiency}

Mean erythrocyte G6PD levels were significantly $(\mathrm{p}<0.001)$ lower among the groups and was also in comparison to that of group A. Again, significantly lower level of this enzyme were observed between groups $\mathrm{Avs}_{2}(\mathrm{p}<0.01)$ and $A$ vs $B_{3}(p<0.001)$ and also between $B_{1}$ vs $\mathrm{B}_{2}, \mathrm{~B}_{2} \mathrm{vs} \mathrm{B}_{3}(\mathrm{p}<0.05)$ and between $\mathrm{B}_{1}$ vs $\mathrm{B}_{3}$ $(p<0.01)$. On the other hand no significant difference was observed between $A$ vs $B_{1}$ (Table I).

Table 1 : Erythrocyte G6PD level in different groups of neonates $(n=120)$.

\begin{tabular}{lcc}
\hline Groups & $\mathrm{N}$ & $\mathrm{mU} / 10^{9} \mathrm{RBC}$ \\
\hline $\mathrm{A}$ & 30 & $290.20 \pm 30.04$ \\
& & $(251-351)$ \\
$\mathrm{B}_{1}$ & 30 & $280.90 \pm 29.01$ \\
& & $(245-344)$ \\
$\mathrm{B}_{2}$ & 30 & $263.77 \pm 30.64$ \\
& & $(137-311)$ \\
$\mathrm{B}_{3}$ & 30 & $232.77 \pm 77.58$ \\
& & $(49-304)$ \\
\hline
\end{tabular}

Statistical analysis:

\begin{tabular}{lc}
\hline Groups & p value \\
\hline $\mathrm{A}_{\text {vs }} \mathrm{B}_{1}$ vs $\mathrm{B}_{2}$ vs $\mathrm{B}_{3}$ & $0.000^{* * *}$ \\
$\mathrm{~A}$ vs $\mathrm{B}_{1}$ & $0.228^{\text {ns }}$ \\
$\mathrm{A}$ vs $\mathrm{B}_{2}$ & $0.001^{* *}$ \\
$\mathrm{~A}$ vs $\mathrm{B}_{3}$ & $0.000^{* * *}$ \\
$\mathrm{~B}_{1}$ vs $\mathrm{B}_{2}$ & $0.030^{*}$ \\
$\mathrm{~B}_{1}$ vs $\mathrm{B}_{3}$ & $0.002^{* *}$ \\
$\mathrm{~B}_{2}$ vs $\mathrm{B}_{3}$ & $0.046^{*}$ \\
\hline
\end{tabular}

Group A = Apparently healthy neonates(control $<5 \mathrm{mg} / \mathrm{dl}$ ).

Group $B_{1}=$ Total serum bilirubin level $<15 \mathrm{mg} / \mathrm{dl}$.

Group $B_{2}=$ Total serum bilirubin level $15-20 \mathrm{mg} / \mathrm{dl}$.

Group $B_{3}=$ Total serum bilirubin level $>20 \mathrm{mg} / \mathrm{dl}$.

$* * *=\mathrm{p}<0.001 . \quad \mathrm{ns}=$ Not significant.

$* *=\mathrm{p}<0.01 . \mathrm{n}=$ Number of subjects

* $\quad \mathrm{p}<0.05$

18
Mean hemoglobin concentration were significantly $(\mathrm{p}<0.05)$ lower among the groups. Again, significantly lower concentration of hemoglobin were found between groups $\mathrm{A}_{\mathrm{vs}} \mathrm{B}_{3}$ $(\mathrm{p}<0.01)$ and also $A$ vs $B_{2}(p<0.05)$. On the other hand, the differences of these values were non significant between $A$ vs $B_{1}$ and also $B_{1}$ vs $B_{2}$, $B_{1}$ vs $B_{3}$ and $B_{2}$ vs $B_{3}$ (Table II).

Mean hematocrit \& total count of red blood cells were significantly $(\mathrm{p}<0.01)$ lower among the groups and also between $A$ vs $B_{2} \& A$ vs $\mathrm{B}_{3}(\mathrm{p}<0.01)$ \& $\mathrm{A}$ vs $\mathrm{B}_{1}(\mathrm{p}<0.05)$. On the other hand, no significant difference were observed between groups $B_{1}$ vs $B_{2}, \quad B_{1}$ vs $B_{3}$ and $B_{2}$ vs $B_{3}$ (Table II).

Significantly $(\mathrm{p}<0.001)$ higher reticulocytes count were observed among the groups and between $A$ vs $B_{1}$, A vs $B_{2}$ and $A$ vs $B_{3}$ and also between groups $B_{1}$ vs $B_{3}$ and $B_{2}$ vs $B_{3}$. On the other hand, reticulocytes count were slightly higher in group $\mathrm{B}_{2}$ in comparison to group $\mathrm{B}_{1}$ but difference was non significant (Table II)

Though, the percentages of the subjects with higher reticulocyte count were observed in group $B_{3}$ than those of $B_{1}$ and $B_{2}$ but significant differences were observed between groups $\mathrm{B}_{1} \mathrm{vs}_{3}(\mathrm{p}<0.01)$ and also between groups $\mathrm{B}_{2}$ vs $B_{3}(p<0.05)$ whereas, difference was non significant between groups $B_{1}$ and $B_{2}$ (Figure 1).

Hemoglobin concentration, hematocrit level, total red blood cells \& reticulocyte count showed non significant positive correlations $(\mathrm{r}=+.745, \mathrm{r}=+.205$, $\mathrm{r}=+.329$, $\mathrm{r}=+.104$ ) with erythrocyte G6PD level in deficient neonates (Table III).

J Bangladesh Soc Physiol. 2011 June; 6(1): 16-21 
Hematological Status in Neonatal Jaundice Patients and Its Relationship with G6PD Deficiency

Article

Table II: Hemoglobin concentration, Hematocrit, Total count of RBC and Reticulocyte count in different groups of neonates $(n=120)$.

\begin{tabular}{|c|c|c|c|c|c|}
\hline Groups & $\mathrm{n}$ & $\mathrm{Hb}(\mathrm{g} / \mathrm{dl})$ & Hematocrit (\%) & $\mathrm{RBC}\left(10^{12} / \mathrm{L}\right)$ & Reticulocyte \% \\
\hline \multirow[t]{2}{*}{ A } & 30 & $17.00 \pm 2.48$ & $48.85 \pm 7.82$ & $4.65 \pm 0.58$ & $1.45 \pm 0.49$ \\
\hline & & $(9.7-20.3)$ & $(28.3-58)$ & $(3.04-5.4)$ & $(1-3)$ \\
\hline \multirow[t]{2}{*}{$\mathrm{B}_{1}$} & 30 & $15.66 \pm 3.36$ & $42.90 \pm 10.17$ & $4.23 \pm 0.90$ & $2.63 \pm 1.43$ \\
\hline & & $(8-23)$ & $(29.2-64.6)$ & $(2.9-5.9)$ & $(1-7)$ \\
\hline \multirow[t]{2}{*}{$\mathrm{B}_{2}$} & 30 & $15.43 \pm 2.06$ & $42.54 \pm 7.48$ & $3.99 \pm 0.8$ & $3.14 \pm 1.58$ \\
\hline & & $(8.5-20)$ & $(27.5-54.2)$ & $6(2.1-5.46)$ & $(1.3-7)$ \\
\hline \multirow[t]{2}{*}{$\mathrm{B}_{3}$} & 30 & $14.53 \pm 3.59$ & $41.49 \pm 10.02$ & $3.98 \pm 0.84$ & $5.70 \pm 1.60$ \\
\hline & & $(7-20.3)$ & $(27-59.8)$ & $(2.5-5.7)$ & $(3-10)$ \\
\hline
\end{tabular}

Statistical analysis:

\begin{tabular}{lcrrc}
\hline Groups & \multicolumn{3}{c}{ p value } \\
\hline $\mathrm{A}$ vs $\mathrm{B}_{1}$ vs B $_{2}$ vs $\mathrm{B}_{3}$ & $0.032^{*}$ & $0.008^{* *}$ & $0.005^{* *}$ & $0.000^{* * *}$ \\
$\mathrm{~A}$ vs $\mathrm{B}_{1}$ & $0.099^{\mathrm{ns}}$ & $0.036^{*}$ & $0.038^{*}$ & $0.000^{* * *}$ \\
$\mathrm{~A}$ vs $\mathrm{B}_{2}$ & $0.032^{*}$ & $0.002^{* *}$ & $0.001^{* *}$ & $0.000^{* * *}$ \\
$\mathrm{~A}$ vs $\mathrm{B}_{3}$ & $0.003^{* *}$ & $0.002^{* *}$ & $0.001^{* *}$ & $0.000^{* * *}$ \\
$\mathrm{~B}_{1} \mathrm{vs} \mathrm{B}_{2}$ & $0.797^{\mathrm{ns}}$ & $0.875^{\mathrm{ns}}$ & $0.293^{\mathrm{ns}}$ & $0.195^{\mathrm{ns}}$ \\
$\mathrm{B}_{1} \mathrm{vs} \mathrm{B}_{3}$ & $0.230^{\mathrm{ns}}$ & $0.592^{\mathrm{ns}}$ & $0.259^{\mathrm{ns}}$ & $0.000^{* * *}$ \\
$\mathrm{~B}_{2}$ vs $\mathrm{B}_{3}$ & $0.294^{\mathrm{ns}}$ & $0.647^{\mathrm{ns}}$ & $0.947^{\mathrm{ns}}$ & $0.000^{* * *}$ \\
\hline
\end{tabular}

Figures in parentheses indicate ranges.

$* * *=0<0.001$

$* *=\mathrm{p}<0.01$.

ns $=\mathrm{P}>0.05$

$*=\mathrm{p}<0.05$.

Table III: Correlations of different hematological parameters with G6PD level in G6PD deficient neonates $(n=7)$

\begin{tabular}{lcc}
\hline Parameters: & $\mathrm{r}$ & $\mathrm{p}$ \\
\hline Hemoglobin & $+.745^{\mathrm{ns}}$ & 0.055 \\
Hematocrit & $+.205^{\mathrm{ns}}$ & 0.659 \\
Red blood cell & $\mathrm{r}=+.329^{\mathrm{ns}}$ & 0.592 \\
Reticulocytes & $+.104^{\mathrm{ns}}$ & 0.825 \\
\hline
\end{tabular}

ns $=$ Not significant

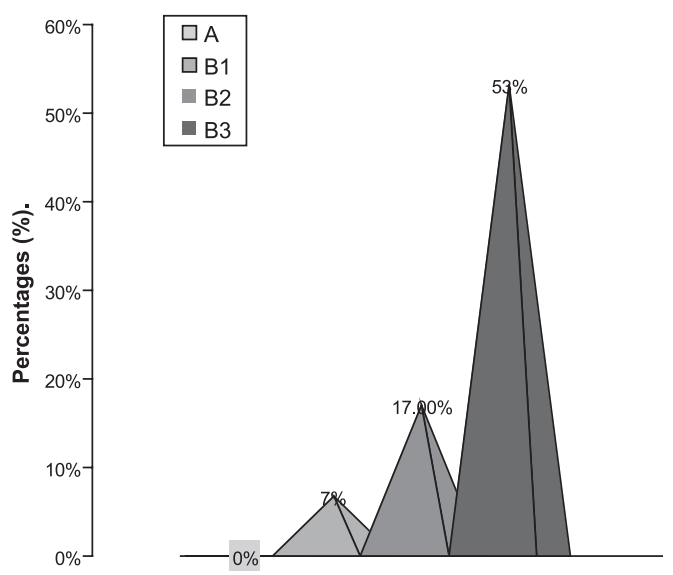

Figure 1: Distribution of the subjects by higher reticulocyte count $(n=120)$

J Bangladesh Soc Physiol. 2011 June; 6(1): 16-21 


\section{Article Hematological Status in Neonatal Jaundice Patients and Its Relationship with G6PD Deficiency}

\section{Discussion}

In the present study significantly lower value of hemoglobin concentration, hematocrit level and red blood cell count were found among the groups and also in severe hyperbilirubinemic group in comparison to that of healthy control, some investigators from different countries also made similar observations ${ }^{10-12}$.

In this study, significantly higher reticulocytes count were observed among the groups and also between mild vs severe hyperbilirubinemic and moderate vs severe hyperbilirubinemic groups $\left(B_{1}\right.$ vs $B_{3}$ and $B_{2}$ vs $B_{3}$ ). Though, reticulocytes count were slightly higher in moderate hyperbilirubinemic group in comparison to mild group but difference was non significant. This result is similar to the findings reported by different investigators of other countries $8,9,12$.

In this study 53\% of the subjects had higher reticulocyte count in severe hyperbilirubinemic group $\left(B_{3}\right)$ than those of mild $\left(B_{1}\right)$ and moderate $\left(\mathrm{B}_{2}\right)$ groups but significant differences were found between $B_{1}$ vs $B_{3}(p<0.01)$ and $B_{2}$ vs $\mathrm{B}_{3}(\mathrm{p}<0.05)$ whereas, difference was non significant between groups $B_{1}$ and $B_{2}$. Investigators from Neonatal Unit Birmingham Womens Hospital also found similar result ${ }^{12}$.

It is well recognized that hyperbilirubinemia in this group of deficient neonates is hemolytic in origin $^{2,11}$. It has been suggested that in G6PD deficiency, the oxidative stress process would not be counteracted, so stability of erythrocytes is impaired which leads to destruction of RBC more rapidly than normal cells which subsequently metabolized and form bilirubin and leads to hyperbilirubinemia ${ }^{5,18}$.

Various investigators suggested that, lower level of hemoglobin concentration, total count of RBC and hematocrit are the consequences of hemolysis in jaundiced neonates with G6PD deficiency and their changes is depend on degree of deficiency ${ }^{6}$.

Some investigators suggested that, excessive destruction of red blood cells leads to stimulation of erythropoesis and followed by higher reticulocyte count in G6PD deficient neonates. In addition, increased reticulocyte count is also likely to be due to increased rate of erythropoesis to compensate the hemolysis in this enzyme deficient state ${ }^{11,19}$.

In the present study, membrane integrity defect is most likely to be the cause of excess hemolysis as evidenced by maximum number of the G6PD enzyme deficient neonates in severe hyperbilirubinemic group. Increased compensatory erythropoiesis after hemolysis is likely to occur in severe hyperbilirubinemic neonates of the present series as evidenced by their increased reticulocytes count. Positive correlation of hemoglobin concentration, hematocrit, total count of red blood cell \& reticulocyte count with erythrocyte G6PD level also support the presence of excess hemolysis in G6PD deficient neonates.

\section{Conclusion}

From the results of the study it can be concluded that hemolysis is one of the risk factor to develope hyperbilirubinemia in G6PD deficient neonates and degree of hemolysis depends on state of deficiency .

\section{Acknowledgment}

The authors of this article acknowledge all parents of the participant of this study and Dhaka Shishu Hospital for giving permission for sample collection and laboratory facility.

\section{Author Affiliations}

$1 *$ Nilufa Akhter. Assistant Professor of Physiology, Bangladesh Institute of Child Health, Dhaka Shishu Hospital, Dhaka, Bangladesh. Email: nilufa61@yahoo.com.

2. Professor Noorzahan Begum, former Chairman of Physiology, BSMMU, Shahbag, Dhaka, Bangladesh. Email: noorzahan52@.com.

3. Sultana Ferdousi, Associate Professor of Physiology, BSMMU, Shahbag, Dhaka, Bangladesh. Email: sferdousiratna@yahoo.com.

*for correspondance

J Bangladesh Soc Physiol. 2011 June; 6(1): 16-21 
Hematological Status in Neonatal Jaundice Patients and Its Relationship with G6PD Deficiency

Article

\section{References:}

1. ChanTK. Erythrocyte Glucose-6-Phosphate Dehydrogenase Deficiency. The bulletin of the Hong kong Chinese Medical Association. 1968; 20: 34-44.

2. Beutler E. G6PD deficiency. Blood . 1994; 84(11): 3616-3636.

3. Carter SM, Gross SJ. Glucose-6-phosphate Dehydrogenase Deficiency. [Internate]. 2005 Aug 29 [cited 2007 Nov 21]. Available from: http:/ www. emedicine. Com/med/opic 900.htm.

4. Mehta A, Mason JP, Vulliamy JT. Glucose -6phosphate dehydrogenase deficiency. Baille Clin. Haematol. 2000; 13(1): 21-38.

5. Kaplan M, Algur N, Hammerman C. Onset of jaundice in Glucose-6-phosphate Dehydrogenase Deficient Neonates. J Am Acad Pediatr. 2001; 108(4): 956-59

6. Mritunjay P, Anjali K, Vidya G, Sushma K, Saroja B. Neonatal Screening For Glucose-6-Phosphate Dehydrogenase Deficiency. Indian J Pediatr. 2005; 72(10): 835-37.

7. Lai HC, Lai PYM, Leung SNK. Glucose-6Phosphate Dehydrogenase Deficiency In Chinese. J. Clin. Path. 1968; 21: 44-47.

8. Al-Omran A, Al-Ghazal F, Gupta S, Jhon TB. Glucose-6-Phosphate Dehydrogenase Deficiency And Neonatal Jaundice In Al- Hofuf Area. Ann Trop Paediatr. 1998; 7(2): 98-140.

9. Arif A, Bhutta JA. Risk Factors And Spectrum Of Neonatal Jaundice In A Birth Cohort In Karachi. Pakistan Pediatric J. 1988; 30: 213-17.

10. Hafez M, Amar ES, Zedan M, Hammad H, Sorour AH, Desouky SA, Gami N. Improved Erythrocyte Survival With Combined Vitamin E And Selenium
Therapy In Children With G6PD Deficiency And Mild Chronic Hemolysis. J Pediatr. 1986; 108:55861.

11. Kaplan M, Hammerman C. Glucose-6-Phosphate Dehydrogenase Deficiency: A Worldwide Potential Cause of Severe Neonatal Hyperbilirubinemia. Pediatrics in Review Neo Reviews. 2000; 1: 32-39.

12. Dhillon A, Darbyshire PJ, Williams M.D, Bissenden JG. Massive Acute Haemolysis In Neonates With Glucose-6-Phosphate Dehydrogenase Deficiency. Arch of Dis in childhood fetal and neonatal 2003; 88: 534-39.

13. Ishay DB, Izak G. Chronic Hemolysis Associated With Glucose-6-Phosphate Dehydrogenase Deficiency. J Lab Clin Med. 1964; 63(6): 1002-08.

14. Sultana N, Begum N, Begum S, Ferdousi S, Ali T. Effects Of Vitamin E Supplementation On Some Aspect Of Hematological Variable In Patient Of Hemolytic Anemic Patient With Glucose-6Phosphate Dehydrogenase Deficiency. Bangladesh Jf Physiol Pharmacol. 2006; 22(1/2):12-17.

15. Abolghashemi H, Mehrani H, Amid A. An update on the prevalence of glucose-6-phosphate dehydrogenase deficiency and neonatal jaundice in Tehran neonates.Clin Biochem. 2004; 37(3): 24144.

16. Jendrassik L, Grof P. Biochem Z. 1938; 81: 297.

17. Dacie SJV, Lewis SM. Practical Hematology. London: ELBS; 1994. 13-17p.

18. Gostman I, Muskat M. Acute Viral Hepatitis And Glucose-6-Phosphate Dehydrogenas Deficiency. J Gasteroenterol And Hepatol. 2001; 16:1239-43.

19. Ardhakani SB, Nikkhah A, Sedaghat M. The Association Between G6PD Deficiency And Total Serum Bilirubin Level In Icteric Neonates. Acta Medica Iranica. 2007; 45(3): 233-35. 